\title{
Temperature-Induced Change of Variant Surface Antigen Expression in Paramecium Involves Antigen Release into the Culture Medium with Considerable Delay between Transcription and Surface Expression
}

\author{
M. Momayezi ${ }^{1}$, P. Albrecht ${ }^{2}$, H. Plattner ${ }^{1}$, H. J. Schmidt ${ }^{2}$ \\ ${ }^{1}$ Department of Biology, University of Konstanz, P.O. Box 5560, 78457 Konstanz, Germany \\ ${ }^{2}$ Department of Biology, University of Kaiserslautern, P.O. Box 3049, 67653 Kaiserslautern, Germany
}

\begin{abstract}
We analyzed temperature-induced changes of variant surface antigen (vsAg) expression in $\mathrm{Pa}$ ramecium primaurelia, using immuno-techniques and mRNA determinations. Upon a $23^{\circ} \mathrm{C}$ to $33^{\circ} \mathrm{C}$ shift, the old vsAg, type $156 \mathrm{G}$, remains on the cell surface for a time, when already mRNA for the new form, $156 \mathrm{D}$, is expressed. A considerable amount of 156Dspecific mRNA is formed $45-48 \mathrm{~h}$ after the temperature shift, while $156 \mathrm{D}$ surface expression reaches maximal levels only after $>72 \mathrm{~h}$. A new aspect of these experiments is that, during this transition, the old vsAg is steadily released in high-molecular-weight form into the culture medium, as found by dot blot and Western blot analysis of concentrated culture medium. The new vsAg form is first inserted into the somatic cell membrane, before it spreads also into cilia. In the reverse transition, $33^{\circ} \mathrm{C}$ to $23^{\circ} \mathrm{C}$, the adaptation on the level of transcription and surface expression is considerably faster. While we had previously shown, under steady-state conditions (constant temperature), the occurrence of a degradation pathway by endocytotic and phagocytotic ingestion of vsAg this may proceed in parallel to the steady release of old vsAg from the cell surface into the medium. Altogether these combined processes may facilitate the installation of the new vsAg type.
\end{abstract}

Key words: Cilia - Immobilization antigens $-\mathrm{Pa}$ ramecium - Protozoa - Variant surface antigens

Correspondence to: H. Plattner; email: helmut.plattner@, uni-konstanz.de

\section{Introduction}

A Paramecium cell is completely covered by densely packed $\geq 250 \mathrm{kDa}$ large variant surface antigens (vsAg), which are inserted in the cell membrane by a glycosylphosphatidylinositol (GPI) anchor. In the case of Paramecium, the GPI anchor is endowed with a ceramide basepiece (Capdeville, 2000). Antibodies (AB) against these proteins immobilize the cells and therefore vsAg are commonly called immobilization antigens. They are used to characterize different serotypes, since under steady-state conditions only one type of vsAg is expressed - a phenomenon called "mutually exclusive expression" (Antony \& Capdeville, 1989). The different vsAg protein types are encoded by different genes (Preer et al., 1981; 1987) whose expression can be changed by a temperature shift (Antony \& Capdeville, 1989; Benwakrim et al., 1998; Kusch \& Schmidt, 2001).

For the present work we used $P$. primaurelia, for which the corollaries of selective vsAg expression are particularly well established (Beale, 1954). Cells cultivated at $23^{\circ} \mathrm{C}$ express the G-type vsAg (vsAg-G), while they change to vsAg-D upon transfer to $33^{\circ} \mathrm{C}$ (Antony \& Capdeville, 1989). Under steady-state conditions, when a permanent turnover of vsAg takes place, we had traced in $P$. tetraurelia a degradation pathway by internalization via the endocytosis and phagocytosis route, ending up in digestive vacuoles (Flötenmeyer et al., 1999). In contrast to this, little is known about the mechanism how such exchange of vsAg on the cell surface takes place during experimental serotype change, e.g., caused by a temperature shift. In the present study, using $\mathrm{AB}$ binding and mRNA assays, we find evidence for a release into the culture medium, with considerable delay after transcription of 

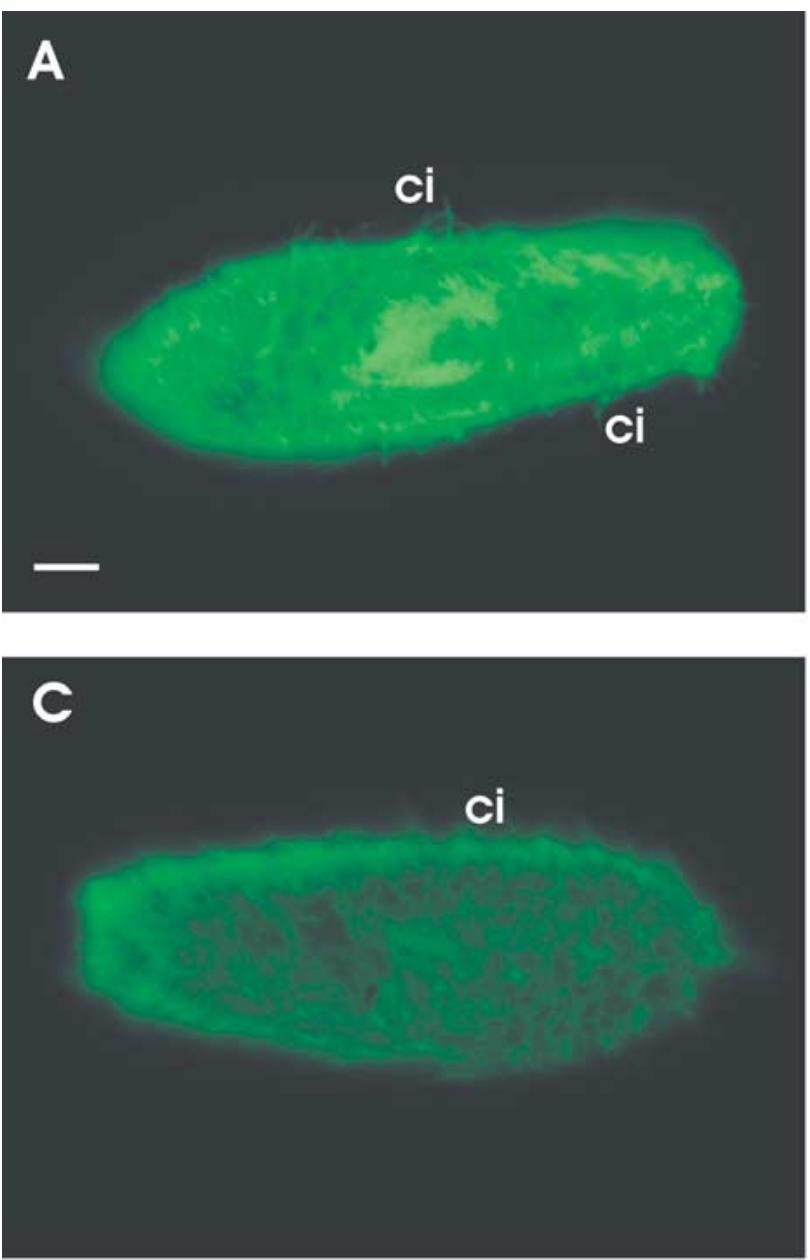

E

Fig. 1. Fluorescence analysis of the transition of vsAg-G to vsAg$\mathrm{D}$, as seen in $A-D, 48,72$ and $96 \mathrm{~h}$, respectively, after a temperature shift $\left(23^{\circ} \mathrm{C}\right.$ to $\left.33^{\circ} \mathrm{C}\right)$, by labeling with $\mathrm{AB}$ against the respective antigens (see text). Green: AB against vsAg-G; red: AB against vsAg-D. (A) Persistence of vsAg-G on the cell surface, $48 \mathrm{~h}$ after transfer. Also note staining of cilia $(c i)$. (B) Absence of vsAg-D staining $48 \mathrm{~h}$ after transfer. $(C)$ Reduction of vsAg-G staining $72 \mathrm{~h}$
B
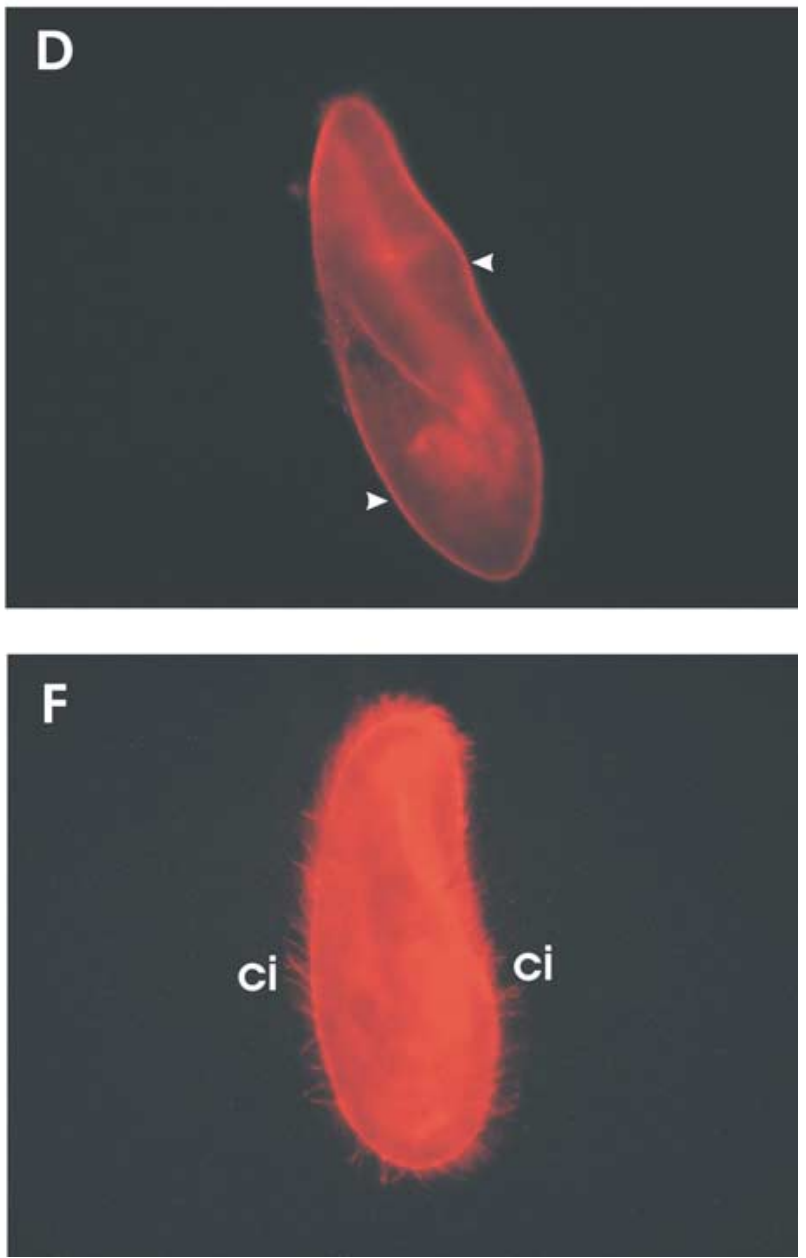

after the temperature shift (compare with $[A]$ ). (D) Emergence of vsAg-D staining $72 \mathrm{~h}$ after transfer on the somatic cell surface, but not in cilia (compare with $[A, C]$ ), e.g., at arrowheads. $(E)$ Disappearance of vsAg-G staining after $96 \mathrm{~h}$, while the surface staining, including cilia $(c i)$, with $\mathrm{AB}$ against vsAg-D $(F)$ is complete. Magnification $700 \times$. 

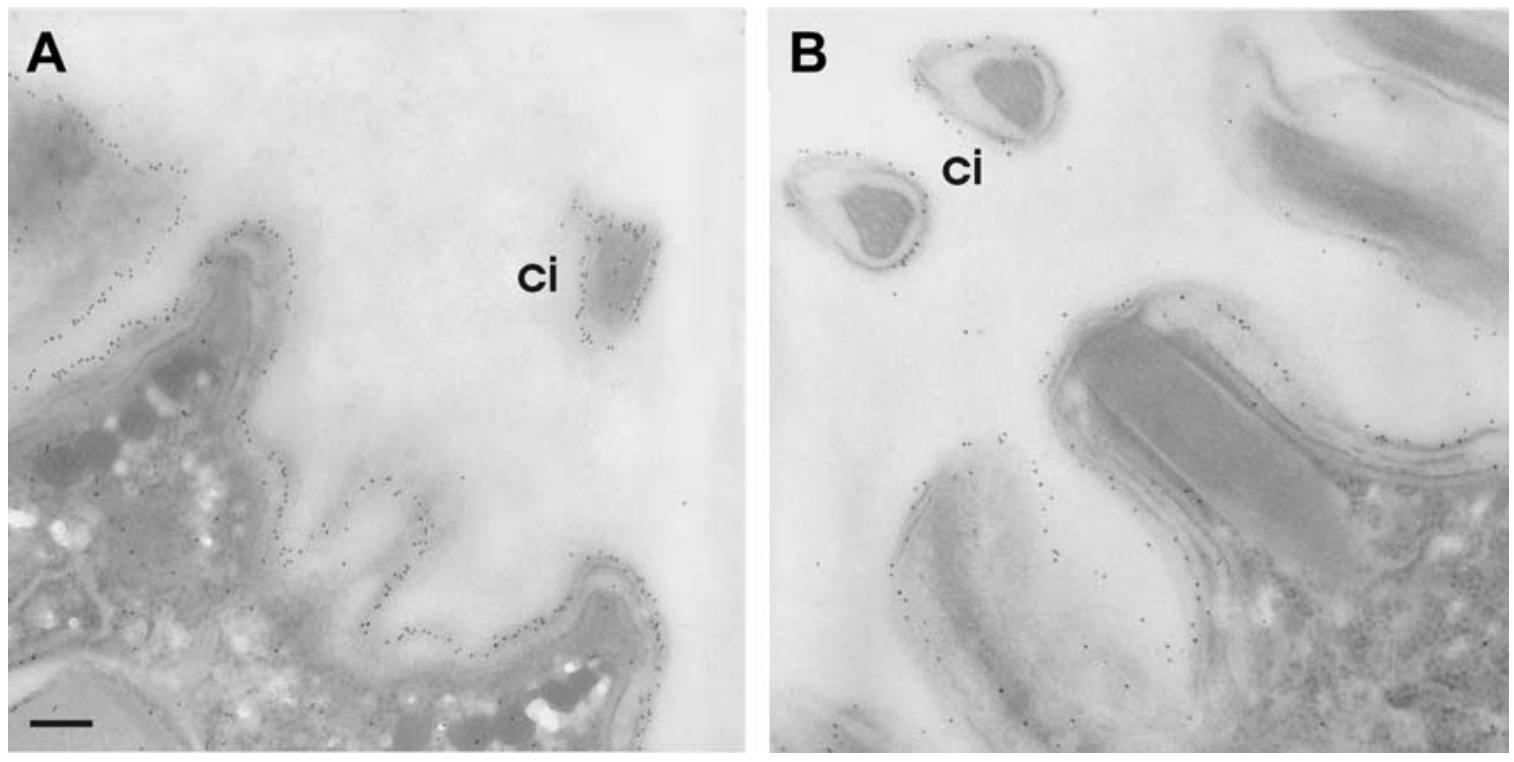

Fig. 2. Electron microscopy (EM) immuno-gold labeling of G- $(A)$ and D-type $(B)$ cells, analyzed under steady-state conditions, i.e., after latent cultivation at $23^{\circ} \mathrm{C}$ and $33^{\circ} \mathrm{C}$, respectively. Note homogeneous labeling with protein $\mathrm{A}-\mathrm{Au}_{5} \mathrm{~nm}$ of the entire cell surface, including cilia, $(A)$ with $\mathrm{AB}$ against vsAg-G in a G-type cell and with $\mathrm{AB}$ against vsAg-D in a D-type cell $(B)$, respectively. Magnification $60,000 \times$.

\section{the mRNA for the induced new vsAg type and its surface expression.}

\section{Materials and Methods}

\section{Strains and Cell Culture}

Paramecium primaurelia, strain 156 (New Haven, CT) was grown in a wheat grass powder medium bacterized with Enterobacter aerogenes the day before use. Cultivation of serotype $156 \mathrm{G}$ was carried out at $23^{\circ} \mathrm{C}$ according to Sonneborn (1947). Cells expressing serotype $156 \mathrm{D}$ were cultivated at $33^{\circ} \mathrm{C}$.

\section{Induction of SERotypes}

To induce serotype $156 \mathrm{D}$ we utilized the method of daily isolating lines. Isolated cells were incubated overnight at $4^{\circ} \mathrm{C}$ and then the cultivation temperature was suddenly changed to $33^{\circ} \mathrm{C}$. After division overnight, only one cell was isolated and transferred into fresh medium with E. aerogenes. After cultivation at $33^{\circ} \mathrm{C}$ overnight, this procedure was repeated for 10 days. By that time all cells had been transformed to serotype $156 \mathrm{D}$. To induce serotype $156 \mathrm{G}$, the procedure is simpler, i.e., cells expressing $156 \mathrm{D}$ at $33^{\circ} \mathrm{C}$ were cultivated at room temperature $\left(23^{\circ} \mathrm{C}\right)$ for the time indicated in text and figure legends to transform them into serotype $156 \mathrm{G}$. Henceforth these strains are designated as vsAg-G and vsAg-D, respectively.

This methodology implies the following. For inducing a change in expression of serotype, strong signals are most efficient. Changing the cultivation temperature from $4{ }^{\circ} \mathrm{C}$ to $33^{\circ} \mathrm{C}$ is such a strong signal, resulting in cells clearly expressing serotype D. Although a rather high number of cells does not survive this harsh but most effective treatment, the number of surviving cells (50 to 70\%) is sufficient when working with daily isolation lines. A similar experiment to induce serotype $\mathrm{G}$ by changing culture conditions from $33^{\circ} \mathrm{C}$ down to $4^{\circ} \mathrm{C}$ is lethal for all cells. Therefore, in this case, only a shift to $23^{\circ} \mathrm{C}$ has been applied, resulting in a reliable transformation from vsAg-D to vsAg-G.

\section{Isolation of Surface Antigens}

A defined number of vsAg-G or vsAg-D cells were washed in $10 \mathrm{~mm}$ PIPES-buffer $\mathrm{pH} 7.2$ and divided into five portions, each with $1.5 \times 10^{5}$ cells, in $40 \mathrm{ml}$ fresh bacterized culture medium. Cells were grown under the two conditions, (i) after a shift from $23^{\circ} \mathrm{C}$ to $33^{\circ} \mathrm{C}$ and (ii) after a shift from $33^{\circ} \mathrm{C}$ to $23^{\circ} \mathrm{C}$.

For the isolation of vsAg samples the methods of Preer (1959) and Jones (1965) were applied. Briefly, 10 to 15 liters of mass culture were centrifuged in a liquid separator at $1,000 \times g$ to obtain $400 \mathrm{ml}$ of concentrated cells. This volume was washed twice in Dryl's phosphate buffer, $\mathrm{pH} 6.8$ (in mм: $1 \mathrm{NaH}_{2} \mathrm{PO}_{4}, 1$ $\mathrm{Na}_{2} \mathrm{HPO}_{4}, 2 \mathrm{Na}_{3}$ citrate, $1 \mathrm{CaCl}_{2}$ ). Cells were concentrated once more to a volume of $5 \mathrm{ml}$ and then suspended for $1 \mathrm{~h}$ in extraction medium $(12 \%$ ethanol; $7.7 \mathrm{~mm} \mathrm{NaCl})$ at $4{ }^{\circ} \mathrm{C}$. Then the suspension was briefly centrifuged $(180 \times g, 5 \mathrm{~min})$ and the supernatant was again centrifuged $\left(20,000 \times g, 5 \mathrm{~min}, 4^{\circ} \mathrm{C}\right)$ to remove all cell fragments. Proteins were precipitated by adding solid $\left(\mathrm{NH}_{4}\right)_{2} \mathrm{SO}_{4}$ up to $75 \%$ saturation, followed by stirring on ice for $3 \mathrm{~h}$. The isolated surface proteins were centrifuged at $10,000 \times$ $g\left(15 \mathrm{~min}, 4^{\circ} \mathrm{C}\right)$ and then resuspended in $10 \mathrm{ml}$ bidistilled $\mathrm{H}_{2} \mathrm{O}$. This material was dialyzed over $48 \mathrm{~h}$ to remove ions and then lyophilized in a vacuum concentrator.

\section{AB Production}

Isolated vsAg were diluted in phosphate-buffered saline (PBS) $\mathrm{pH}$ 7.2. Protein was used in native form. AB against the respective type of vsAg, after expression by the respective strains and purification, were raised in rabbits. Pre-immune sera were taken and checked for non-reactivity on Western blots and in immunofluorescence.

\section{IMMOBILIZATION REACTION}

The effect of the AB against the respective vsAg was tested under light-microscope control, as described previously (Flötenmeyer et al., 1999). 

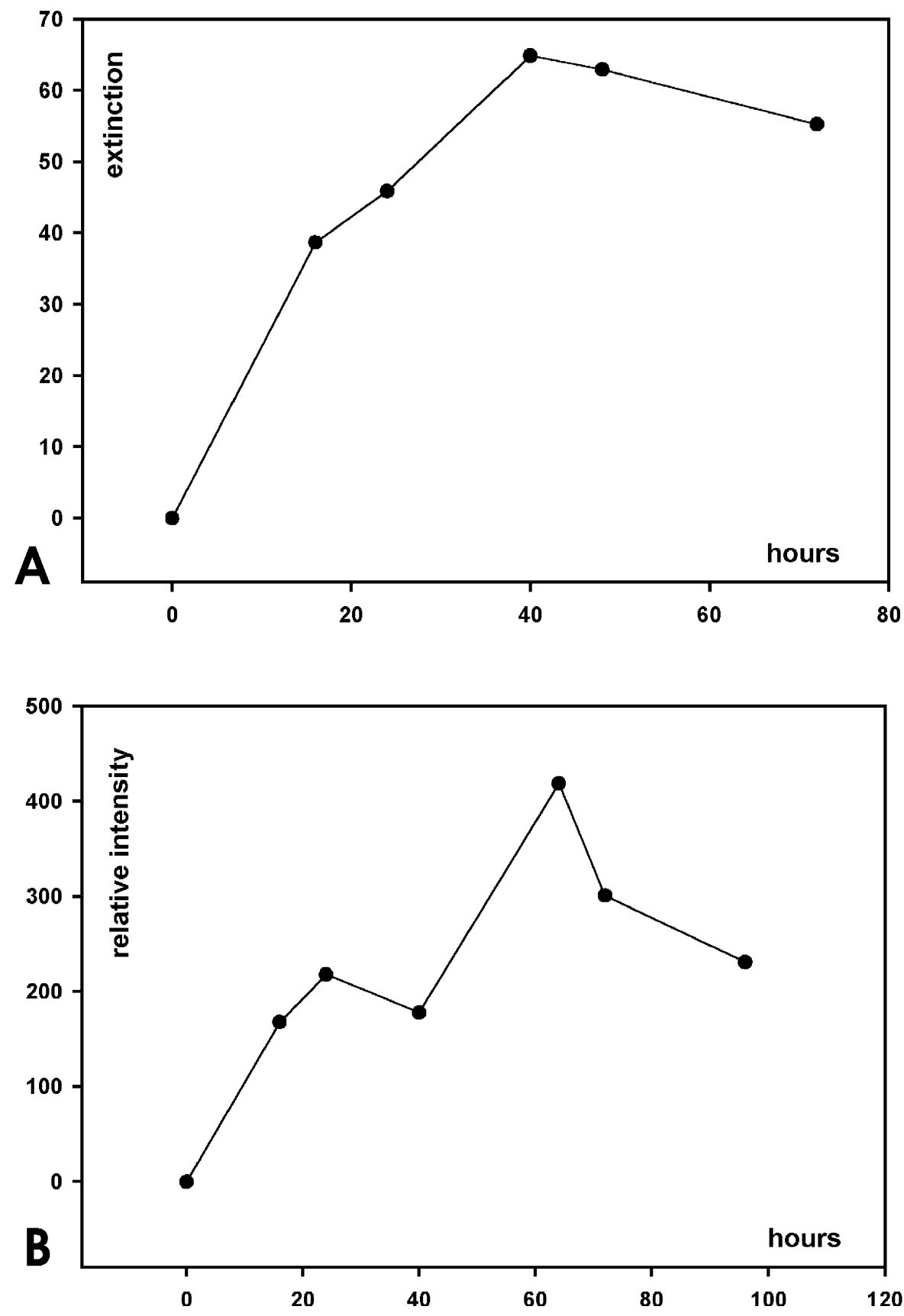

Fig. 3. Typical experiments showing the release of vsAg-G after transfer of cells from $23^{\circ} \mathrm{C}$ to $33^{\circ} \mathrm{C}$, as derived from $\operatorname{dot}$ blot $(A)$ and Western blot analysis $(B)$. Concentrated supernatants from cell culture medium have been probed with AB against vsAg-G as specified in Materials and Methods.

\section{ELISA, Dot Blots and Western Blots}

For ELISA and dot blots, fractions to be analyzed were bound to the wells in different concentrations (to assure concentration-dependent linearity of the reaction) and further processing was by standard methods. Sodium dodecylsulfate (SDS) polyacrylamide gel electrophoresis (PAGE) was performed with gels of 5 to $15 \%$. Samples of concentrated culture medium were applied to gels after brief boiling. The sizes of markers (Pharmacia, Freiburg, Germany) varied between 10 and $250 \mathrm{kDa}$. Gels were stained with silver or alternatively processed for Western blots and treated with antivsAg AB followed by alkaline phosphatase-tagged anti-rabbit AB (Sigma, Taufkirchen, Germany) by standard techniques. Reaction intensities were quantified in a standard scanner.
IMMUNOFLUORESCENCE

Cells were washed in PIPES buffer pH 7.2 and injected as a concentrated suspension into $4 \%$ formaldehyde in PBS pH $7.4\left(20^{\circ} \mathrm{C}\right.$, $30 \mathrm{~min}$ ). Then cells were pelleted, washed in $50 \mathrm{~mm}$ glycine-PBS (3 $\times 10 \mathrm{~min}$ ) and incubated with antisera in PBS, supplemented with $1 \%$ BSA, followed by FITC- or Texas Red-conjugated goat antirabbit-IgG (ICN, Eschwege, Germany). For further details, see Flötenmeyer et al. (1999).

\section{ImMuno-Gold Electron Microscopy}

Cells were washed in Pipes buffer pH 7.2 and fixed in $8 \%$ formaldehyde supplemented with $0.25 \%$ glutaraldehyde in PBS pH 7.4. After 


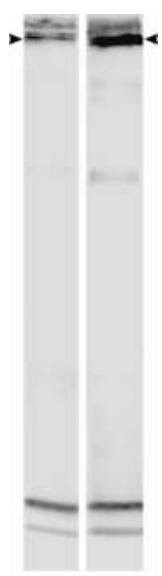

A B

Fig. 4. Western blot analysis of vsAg-G released after transfer of cells from $23^{\circ} \mathrm{C}$ to $33^{\circ} \mathrm{C}$. The vsAg-G released $16 \mathrm{~h}$ and $40 \mathrm{~h}$ after temperature change is of the high molecular weight form ( $\geq 250 \mathrm{kDa}$, between arrowheads) and its intensity increases with time, in agreement with Fig. $3 A$. The higher molecular weight band represents material retained in the stacking gel, while low-size bands at the bottom are of unidentified type and invariably found, independently of the vsAg released.

blocking the reactive aldehyde groups by $50 \mathrm{~mm}$ glycine $(3 \times 10 \mathrm{~min})$ the samples were dehydrated in a graded ethanol series, impregnated with Unicryl (British BioCell Int., London) at $4^{\circ} \mathrm{C}(2 \times 3 \mathrm{~h})$ and UVpolymerized at $-20^{\circ} \mathrm{C}$ according to the manufacturer's advice.

Ultrathin sections were floated on $0.02 \mathrm{M}$ glycine in PBS (10 min), washed in $0.3 \%$ BSA-C (BioTrend, Köln, Germany) in PBS $(2 \times 10 \mathrm{~min})$, incubated for $1 \mathrm{~h}$ with one of the anti-vsAg AB, washed in $0.3 \%$ BSA-C/PBS $(3 \times 10 \mathrm{~min})$ and incubated with protein A-gold of $6 \mathrm{~nm}$ diameter $\left(\mathrm{Au}_{6 \mathrm{~nm}}\right)$ obtained from University of Utrecht (Dept. Cell Biol., School of Medicine, The Netherlands). After washing with distilled water, sections were routinely stained with $2 \%$ aqueous uranyl acetate for electron microscope (EM) analysis.

\section{RT-PCR TEST}

\section{Isolation of $m R N A$}

The cells were washed twice in Dryl's phosphate buffer. Cell lysis and isolation were based on the mRNA Capture Kit from Roche (Mannheim, Germany). The cells were lysed in $50 \mu \mathrm{l}$ buffer, followed by the addition of a biotin-labeled oligo-dT-probe to the lysate. This mixture was incubated at $37^{\circ} \mathrm{C}$ for $10 \mathrm{~min}$ for hybridization of probe and mRNA. The solution was then transferred into a streptavidin-coated micro-testtube (Roche). After further incubation $\left(10 \mathrm{~min}, 37^{\circ} \mathrm{C}\right)$ the $\mathrm{mRNA} /$ probe hybrids bound tightly to the micro-testtube. The cells were washed twice with washing solution (Roche).

\section{Single-Step $R T$-PCR}

The Titan-One-Tube RT-PCR-System ${ }^{\circledR}$ (Roche) was used to carry out the RT-PCR, with the advantage that all reactions took place in the streptavidin-coated micro-testtube used for mRNA isolation.

Two Master Mixes were prepared for reaction.

Master-Mix 1: $4 \mu \mathrm{l}$ dNTP (each $10 \mathrm{~mm}$ ), $1 \mu$ l primer forward $(100 \mathrm{~mm}), 1 \mu \mathrm{l}$ primer reverse $(100 \mathrm{~mm}), 2.5 \mu \mathrm{l}$ dithiothreitol
(100 mm), $0.5 \mu \mathrm{l}$ RNAse inhibitor from human placenta, $16 \mu \mathrm{l}$ bidistilled water, $25 \mu 1$ total volume.

Master-Mix 2: $10 \mu \mathrm{l} 5 \times$ RT-PCR buffer, $1 \mu$ l enzyme mix, 14 $\mu$ bidistilled water, $25 \mu$ l total volume.

Program parameters of the single-step RT-PCR were as follows. Reverse transcription: $30 \mathrm{~min}, 50^{\circ} \mathrm{C}$. Denaturation: $2 \mathrm{~min}$, $94^{\circ} \mathrm{C}$. 10 cycles (denaturation $10 \mathrm{~s}, 94^{\circ} \mathrm{C}$; primer annealing $30 \mathrm{~s}$, $45^{\circ} \mathrm{C}$; primer elongation $45 \mathrm{~s}, 68^{\circ} \mathrm{C}$ ). 25 cycles (denaturation $10 \mathrm{~s}$, $94^{\circ} \mathrm{C}$; primer annealing $30 \mathrm{~s}, 45^{\circ} \mathrm{C}$; primer extension $45 \mathrm{~s}+5 \mathrm{~s} /$ cycle, $68^{\circ} \mathrm{C}$; 1 cycle: primer extension $7 \mathrm{~min}, 68^{\circ} \mathrm{C}$ ).

After the reaction, the product was visualized by Agarose gelelectrophoresis.

\section{Results}

Transformation of serotype $156 \mathrm{G}$ to $156 \mathrm{D}$ was induced by a rapid temperature change as described in "Materials and Methods". This includes incubation of the cells overnight at $4^{\circ} \mathrm{C}$, before transfer to $33^{\circ} \mathrm{C}$. The temperature shock thus produced causes a rather rapid and efficient change of vsAG expression. This change has been analyzed by immuno-fluorescence labeling and in parallel the transcription of the respective genes has been monitored by RT-PCR. Immobilization tests, combined with Western and dot blot analyses, as well as immunolabeling studies showed specifity of the $\mathrm{AB}$ used.

After transfer from $23^{\circ} \mathrm{C}$ to $33^{\circ} \mathrm{C}$, P. primaurelia cells expressing the vsAg type $\mathrm{G}$ change to type vsAg$\mathrm{D}$ only after a rather long time, as visualized by immunofluorescence using $\mathrm{AB}$ against the respective vsAg type (Fig. 1). After $72 \mathrm{~h}$, both vsAg can be seen on cells in transition. One would expect that this change occurs over the entire cell surface, since its localization under steady-state conditions includes the somatic and the ciliary cell membrane. In fact, under such conditions, as we show on micrographs obtained by immuno-gold EM analysis (Fig. 2), the overall localization is rather homogeneous. However, during the temperature-induced vsAg change, we observe after $72 \mathrm{~h}$ a transitional stage where only the somatic cell membrane is labeled by $\mathrm{AB}$ against the new vsAg type, whereas cilia are not (Fig. $1 D$ ).

During the temperature-induced change we have measured by immunological methods the time-dependent occurrence of vsAg-G in the cell culture medium. Assays were done by ELISA or dot blots (Fig. $3 A$ ) and by Western blot analysis of the $\geq 250 \mathrm{kDa}$ large immuno-reactive bands (Fig. $3 B$ ). For these tests the cell culture medium was concentrated as described in "Materials and Methods". In pilot assays, the amount of protein applied per dot or per lane was varied over two orders of magnitude to ascertain linearity of the reaction with $\mathrm{AB}$. Evaluation was by scanning the intensity of the reaction per dot and by scanning the high molecular weight peak areas in Western blots, respectively, also as described. We thus have determined the relative intensity of the 
Table 1. Time-dependency of the change from vsAg-G to vsAg-D following a temperature shift $23^{\circ} \mathrm{C} \rightarrow 33^{\circ} \mathrm{C}$, analyzed by immunofluorescence and mRNA determination by RT-PCR ${ }^{\S}$. Evaluation derived from Figs. 1 and 4.

Time after $23^{\circ} \mathrm{C}$ to $33^{\circ} \mathrm{C}$

Transfer (h)
Immunofluorescence/mRNA

Anti-vsAg-G AB/mRNA-G
Anti-vsAg-D AB/mRNA-D

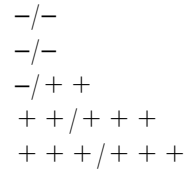

${ }^{\S}$ Rating: (-) no reactivity; $(+)$ to $(+++)$ low to maximal intensity.

immuno-staining achieved with either one of these AB under identical conditions, e.g., with equal amounts of protein applied and equal $\mathrm{AB}$ dilution. Figures $3 A$ and $3 B$ each present data from typical experiments with the two methods described. Clearly, during the $23^{\circ} \mathrm{C}$ to $33^{\circ} \mathrm{C}$ transition, vsAg- $\mathrm{G}$ is released into the medium in intact form, i.e., without change in molecular weight (Fig. 4). This may allow new vsAg molecules to be inserted into the cell membrane, as they substitute for old ones. In all runs, the intensity of the vsAg-G-reactive material contained in the cell culture medium declined roughly after 2 to 3 days following the $23^{\circ} \mathrm{C}$ to $33^{\circ} \mathrm{C}$ transition.

How does that compare with immunofluorescence experiments? According to Fig. 1 and the summary of data contained in Table 1 , the release of vsAg-G decreases during the time when the new type, vsAg-D, is increasingly incorporated into the cell surface. Therefore, the change in the surface composition is not due to an acute release of the old vsAg, but this change is mainly due to a gradual replacement of old vsAg molecules by those of the new type.

How does that compare with the change in the amounts of the mRNA for the respective vsAg types, vsAg-G and vsAg-D, during the $23^{\circ} \mathrm{C}$ to $33^{\circ} \mathrm{C}$ shift? Figure 5 presents a typical example of a RT-PCR evaluation. The readings for the mRNA encoding the G-type vsAg, mRNA-G, disappear between 45 and $48 \mathrm{~h}$ after the temperature shift, while mRNA-D is transcribed to a significant extent after $45 \mathrm{~h}$ and then still increases to a maximal level after $72 \mathrm{~h}$. As summarized in Table 1, the change in mRNA remarkably precedes the expression of the new vsAg on the cell surface. About 3 days are required to achieve the new steady state on the transcriptional level, while about 4 days are required for steady state on the translational level and on the level of transcellular transport to the cell surface. At this time also the original vsAg-G is fully removed from the surface (see Fig. 1).

How does the vsAg expression change during a temperature change in the opposite direction? Changes in vsAg after a temperature shift, $33^{\circ} \mathrm{C}$ to $23^{\circ} \mathrm{C}$, were analyzed in similar experiments, again by

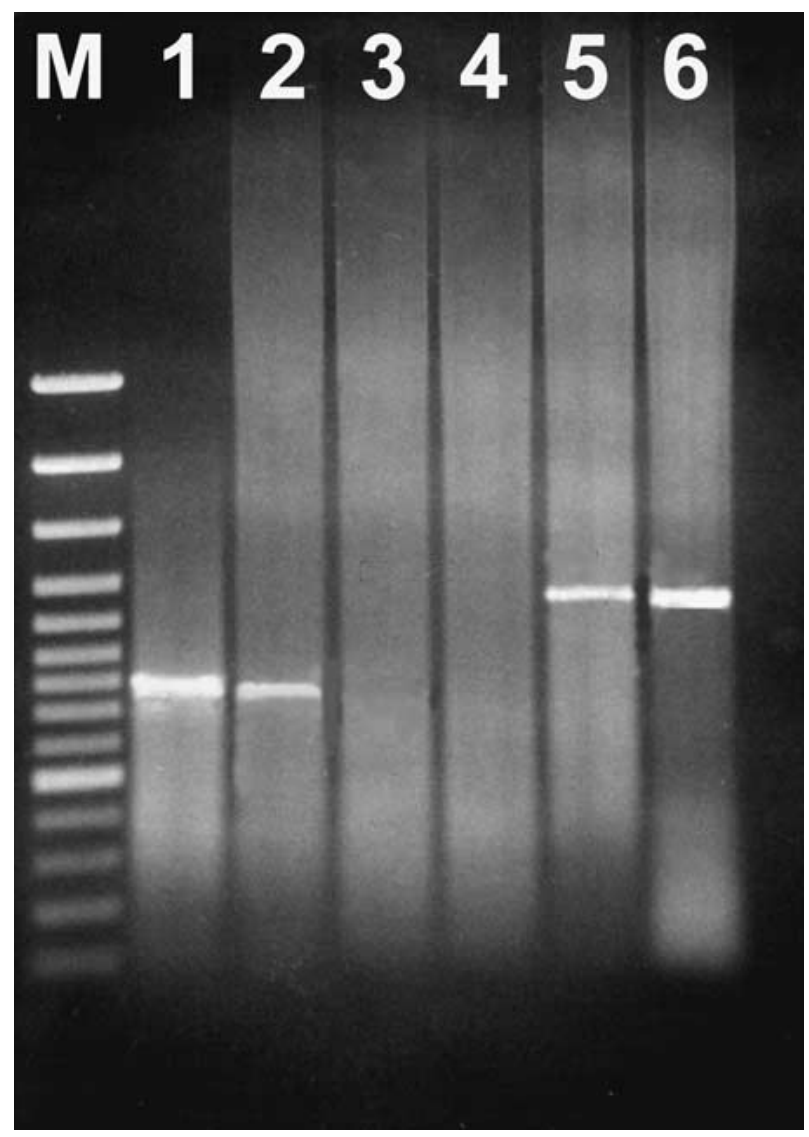

Fig. 5. RT-PCR analysis of the vsAg-G to vsAg-D transition induced by a temperature shift, $23^{\circ} \mathrm{C}$ to $33^{\circ} \mathrm{C}$. $M=$ Marker Gene Ruler 100 bp Ladder Plus MBI; (1-3) vsAg-G specific probe, (4-6) vsAg-D-specific probe. Times after temperature change: $42 \mathrm{~h}(1,4)$, $45 \mathrm{~h}(2,5), 48 \mathrm{~h}(3,6)$. Note that the vsAg-G-specific signal disappears only after $48 \mathrm{~h}$, while the vsAg-D specific signal appears already $3 \mathrm{~h}$ earlier.

combining immunofluorescence and mRNA determinations (Figs. 6, 7). Again a change of vsAg, this time vsAg-D to vsAg-G, can be recognized. In this case, both methods indicate that the change occurs much more rapidly than in the opposite direction. Examples of immuno-fluorescence analysis are shown in Fig. 6, examples of mRNA change are found in Fig. 7. In brief, after a temperature shift from $33^{\circ} \mathrm{C}$ to 


\section{A}

B

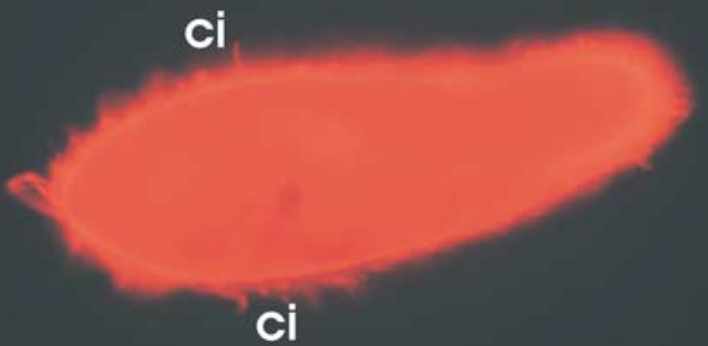

\section{C}

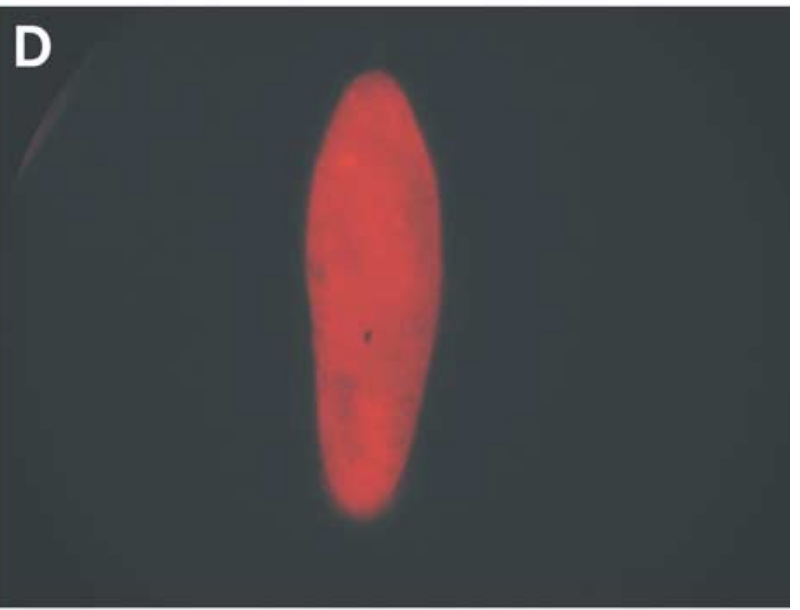

$\mathbf{E}$

$\mathbf{F}$

ci

Fig. 6. Fluorescence analysis of the vsAg-D to vsAg-G transition during a $33^{\circ} \mathrm{C}$ to $23^{\circ} \mathrm{C}$ transfer, using $\mathrm{AB}$ against the respective antigens (see text). Green: $\mathrm{AB}$ against vsAg-G $(A, C, E)$; red: $\mathrm{AB}$ against vsAg-D $(B, D, F)$. After $6 \mathrm{~h}$, staining with $\mathrm{AB}$ against vsAg$\mathrm{G}$ is absent $(A)$, while vsAg-D staining occurs all over the surface, including cilia, $c i(B)$. After $24 \mathrm{~h}$, vsAg-D reactivity is diminished

$23^{\circ} \mathrm{C}$, the new vsAg type can be observed already after $24 \mathrm{~h}$ on the somatic surface (but not on cilia), when the old one is already considerably reduced.
$(D)$, while vsAg-G reactivity occurs on the cell surface, largely with the exception of cilia, as pointed out by the arrowhead $(C)$. After $48 \mathrm{~h}$, staining with $\mathrm{AB}$ against vsAg-D has disappeared $(F)$, while that with $\mathrm{AB}$ against vsAg-G is fully developed, including on cilia, ci $(E)$. Magnification $700 \times$.

After $48 \mathrm{~h}$ the old vsAg type is no longer detectable on the cell surface by immunofluorescence. The change of mRNA species also occurs more rapidly 


\section{M $122344566 \quad 7889101112$ \\ M

Fig. 7. RT-PCR analysis (see Materials and Methods) of the vsAg$\mathrm{D}$ to vsAg-G transition after a temperature shift, $33^{\circ} \mathrm{C}$ to $23^{\circ} \mathrm{C}$. $M=100$ bp DNA Ladder Promega, (1-6) vsAg-G specific probe, (7-12) vsAg-D specific probe. Times after temperature change: $0 \mathrm{~h}$ $(1,7), 4 \mathrm{~h}(2,8), 6 \mathrm{~h}(3,9), 8 \mathrm{~h}(4,10), 12 \mathrm{~h}(5,11)$ and $24 \mathrm{~h}(6,12)$, respectively. Note that the vsAg-D-specific signal disappears after $8 \mathrm{~h}$, when the vsAg-G- and -D-specific signals are equally pronounced.

during a $33^{\circ} \mathrm{C}$ to $23^{\circ} \mathrm{C}$ shift than during one in the opposite direction (Fig. 7). As during the $23^{\circ} \mathrm{C}$ to $33^{\circ} \mathrm{C}$ shift, transcription of the respective mRNA significantly precedes translation, or-more precisely-positioning at the cell surface.

\section{Discussion}

\section{General Aspects}

The vsAg-type proteins are widely distributed among protists (Ferguson, 1999), from pathogenic to harmless forms, including the ciliate Paramecium (Capdeville, 2000). Many details on vsAg expression are known, like the "mutually exclusive expression" in Paramecium when exposed to a temperature shift (Antony \& Capdeville, 1989). The unsettled question, how this change from one type of vsAg to another may occur, was addressed in the present study.

We had previously analyzed the pathways of vsAg turnover under steady-state conditions
(Flötenmeyer et al., 1999). Under these conditions, using AB labeling on the fluorescence and EM level, we could ascertain uptake by endocytic and phagocytic vacuoles and delivery to digestive vacuoles, which would result in degradation. We now find a permanent release into the culture medium. This is a new pathway, which has not been followed up experimentally so far in previous work. We also observed during the studies presented here that $A B$ against vsAg molecules stain food bacteria, which then undergo phagocytotic uptake (data not shown).

For protozoan life under laboratory conditions it may appear irrelevant that the functional significance of vsAg molecules and of their experimentally induceable change is still enigmatic (Bleyman, 1996). Since their discovery in Paramecium (Preer, 1959) widely different hypotheses have been proposed for the function of protozoan GPI-anchored proteins in general, and for those of Paramecium in particular. For Paramecium, hypotheses range from adaptive responses to environmental conditions (Capdeville \& Benwakrim, 1996) to a role in folate receptor signaling (Paquette et al., 2001). In parasites, hypotheses range from host-cell invasion in the cases of Plasmodium (Blackman, 2000), Toxoplasma (Dzierszinski et al., 2000) and Trypanosoma (Lillico et al., 2003) to transmembrane signaling in the fish pathogenic protozoan, Ichthyophthirius (Clark et al., 2001), and induction of tumor necrosis factor in macrophage host cells by Toxoplasma (Debierre-Grockiego et al., 2003). Considering this ever expanding list of potential functions of GPI-anchored surface proteins in these enormously important parasites it is not surprising that the state of knowledge in Paramecium is even less advanced.

An interesting observation we now present is that newly formed vsAg first appears in the somatic cell membrane, and only later on in cilia. This would be compatible with a delivery in the form of "rafts" into the ciliary membrane, just as proposed for other ciliary membrane proteins (Rosenbaum \& Witman, 2002).

\section{How and where Could vsAg Shedding Occur?}

Normally vsAg molecules cover the entire surface of a Paramecium cell (Adoutte et al., 1983; Barnett \& Steers, 1984; Capdeville et al., 1987). To explain release into the medium one would have to consider transport to internalization sites and/or release directly from the surface, i.e., by surface-bound enzymes. Endocytic and phagocytic uptake for intracellular degradation has been analyzed in detail by Flötenmeyer et al. (1999). In addition, in the present study we find a permanent release into the culture medium, which may be prerequisite to phagocytotic uptake (including bacteria with vsAg adsorbed). This new pathway requires a tentative explanation. 
One possibility to release vsAg molecules would be detachment from the GPI anchor by the GPIspecific phospholipase C (PL-C). This enzyme is known to occur in Paramecium where it has been shown that it can cleave vsAg in vitro (Assouz \& Capdeville, 1992). However, its precise localization in the cell is not known. Partial release of an acylated form of ${ }^{35} \mathrm{~S}$-labeled vsAg has been analyzed in Paramecium under steady-state conditions (Deregnaucourt, 1992). The half-life so determined is longer than that of the time course we find during temperature-induced change. Any role of PL-C is enigmatic also in trypanosomatids since their GPI-specific PL-C is not essential for host-cell invasion, though it influences parasitemia (Webb et al., 1997). In Plasmodium, some GPI-anchored surface proteins were shown very recently to be shed by a protease (Howell et al., 2003). Considering the occurrence in the culture medium of vsAg with its original molecular weight, the endo-/lysosomal pathway previously described (Flötenmeyer et al., 1999) may be just one route for vsAg turnover, which may be relevant under steady-state conditions. The situation may be different when a new type of vsAg is induced. This change may then take place-additionally or exclusively_-by the mechanism shown here.

In sum, although potential mechanisms of release are known, it remains to be settled how and where in the cell this may take place-possibly on the cell surface itself.

We gratefully acknowledge the valuable help of Dr. J. Hentschel in image processing, the skillful technical assistance of Ms. Sylvia Kolassa and Lauretta Schade in the EM work and of Ms. I. Traub in evaluating the blots. This work was supported by grants from the Deutsche Forschungsgemeinschaft to H. P and to H. J. S.

\section{References}

Adoutte, A., Ling, K.Y., Chang, S., Huang, F., Kung, C. 1983. Physiological and mutational protein variations in the ciliary membrane of Paramecium. Exp. Cell Res. 148:387-404

Antony, C., Capdeville, Y. 1989. Uneven distribution of surface antigens during antigenic variation in Paramecium primaurelia. J. Cell Sci. 92:205-215

Assouz, N., Capdeville, Y. 1992. Structural comparisons between the soluble and the GPI-anchored forms of the Paramecium temperature-specific 156G surface antigen. Biol. Cell 75:217223

Barnett, A., Steers, E. 1984. Antibody-induced membrane fusion in Paramecium. J. Cell Sci. 65:153-162

Beale, G.H. 1954. The Genetics of Paramecium aurelia. Cambridge University Press, Cambridge, New York

Benwakrim, A., Trémolière., A., Labarre, J., Capdeville, Y. 1998. The lipid moiety of the GPI-anchor of the major plasma membrane proteins in Paramecium primaurelia is a ceramide: variation of the amide-linked fatty acid composition as a function of growth. Protist 149:39-50

Blackman, M.J. 2000. Proteases involved in erythrocyte invasion by the malaria parasite: Function and potential as chemotherapeutic targets. Curr. Drug Targets 1:59-83
Bleyman, L.K. 1996. Ciliate genetics. In: Ciliates - Cells, Organisms. Hausmann, K., Bradbury, P.C. (editors) pp. 291-324, Gustav Fischer Verlag, Stuttgart, Jena

Capdeville, Y. 2000. Paramecium GPI proteins: variability of expression and localization. Protist 151:161-169

Capdeville, Y., Benwakrim, A. 1996. The major ciliary membrane proteins in Paramecium primaurelia are all glycosylphosphatidylinositol-anchored proteins. Eur. J. Cell Biol. 70:339-346

Capdeville, Y., Caron, F., Antony, C., Deregnaucourt, C., Keller, A.M. 1987. Allelic antigen and membrane-anchor epitopes of Paramecium primaurelia surface antigens. J. Cell Sci. 88:553-562

Clark, T.G., Gao, Y., Gaertig, J., Wang, X., Cheng, G. 2001. The I-antigens of Ichthyophthirius multifiliis are GPI-anchored proteins. J. Eukaryot. Microbiol. 48:332-337

Debierre-Grockiego, F., Azzouz, N., Schmidt, J., Dubremetz, J.F., Geyer, H., Geyer, R., Weingart, R., Schmidt, R.R., Schwarz, R.T. 2003. Roles of glycosylphosphatidylinositols of Toxoplasma gondii. Induction of tumor necrosis factor-a production in macrophages. J. Biol. Chem. 278:32987-32993

Deregnaucourt, C. 1992. Turnover of the GPI-anchored surface antigen in Paramecium. Partial release of its acylated form into the culture medium. Eur. J. Protistol. 28:220-225

Dzierszinski, F., Mortuaire, M., Crebron-Delauw, M.F., Tomavo, S. 2000. Targeted disruption of the glycosylphosphatidylinositol-anchored surface antigen SAG3 gene in Toxoplasma gondii decreases host cell adhesion and drastically reduces virulence in mice. Mol. Microbiol. 37:574-582

Ferguson, M.A.J. 1999. The structure, biosynthesis and functions of glycosylphosphatidylinositol anchors, and the contributions of trypanosome research. J. Cell Sci. 112:2799-2809

Flötenmeyer, M., Momayezi, M., Plattner, H. 1999. Immunolabeling analysis of biosynthetic and degradative pathways of cell surface components (glycocalyx) in Paramecium cells. Eur. J. Cell Biol. 78:67-77

Howell, S.A., Wells, I., Fleck, S.L., Kettleborough, C., Collins, C.R., Blackman, M.J. 2003. A single malaria merozoite serine protease mediates shedding of multiple surface proteins by juxtamembrane cleavage. J. Biol. Chem. 278:23890-23898

Jones, I.G. 1965. Immobilization antigen in heterozygous clones of Paramecium aurelia. Nature 207:769

Kusch, J., Schmidt, H.J. 2001. Genetically controlled expression of surface variant antigens in free-living protozoa. J. Membrane Biol. 180:101-109

Lillico, S., Field, M.C., Blundell, P., Coombs, G.H., Mottram, J.C. 2003. Essential roles for GPI-anchored proteins in african trypanosomes revealed using mutants deficient in GPI8. Mol. Biol. Cell 14:1182-1194

Paquette, C.A., Rakochy, V., Bush, A., Van Houten, J.L. 2001. Glycophosphatidylinositol-anchored proteins in Paramecium tetraurelia: possible role in chemoresponse. J. Exp. Biol. 204:2899-2910

Preer, J.R. 1959. Studies on the immobilization antigens of $\mathrm{Pa}$ ramecium. II. Isolation. J. Immunol. 83:378-384

Preer, J.R., Preer, L.B., Rudman, B.M. 1981. mRNAs for the immobilization antigens of Paramecium. Proc. Natl. Acad. Sci. USA 78:6776-6778

Preer, J.B., Preer, L.B., Rudman, B., Barnett, A. 1987. Molecular biology of the genes for immobilization antigens in Paramecium. J. Protozool. 34:418-423

Rosenbaum, J.L., Witman, G.B. 2002. Intraflagellar transport. Nature Rev. Mol. Cell Biol. 3:813-825

Sonneborn, T.M. 1947. Development mechanisms in Paramecium. Growth Symp. 11:291-307

Webb, H., Carnall, N., Vanhamme, L., Rolin, S., Van Den Abbeele, J., Welburn, S., Pays, E., Carrington, M. 1997. The GPIphospholipase $\mathrm{C}$ of Trypanosoma brucei is nonessential but influences parasitemia in mice. J. Cell Biol. 139:103-114 